\title{
O momento do Cirurgião Geral
}

\section{The timing of the Surgeon General}

TCBC Armando de Oliveira e Silva

Presidente do Colégio Brasileiro de Cirurgiões

E 1996 no Vol. XXIII - no 1 desta revista, o ECBC e ExPresidente do Colégio Brasileiro de Cirurgiões, Orlando Marques Vieira, já se manifestava através do Editorial " $\mathrm{Ci}$ rurgião Geral ao final do Século XX" quanto ao destino sombrio que estava sendo traçado para a Cirurgia Geral.

No momento, entendo que o Colégio Brasileiro de Cirurgiões (CBC) tem uma grande responsabilidade no assunto, cabendo a ele criar novas áreas de interesse no sentido de revigorar a posição do cirurgião geral.

A Cirurgia Geral nestes 16 anos que se passaram desde a publicação do Editorial citado, tornou-se cada vez menos atrativa aos novos cirurgiões. A explicação para isso passa por uma série de dificuldades que foram se somando, tomando a formação do cirurgião geral cada vez mais difícil e complexa.

A exigência de mais tempo de treinamento devido à pluralidade de técnicas e procedimentos envolvidos na sua formação e a dificuldade cada vez maior de adaptação aos novos modelos de aprendizado são alguns dos fatores que podem ter contribuído para o êxodo da especialidade.

A Residência Médica em Cirurgia, devido à forma como atualmente está desenhada, promove uma formação insuficiente ao recém-formado. No momento, passa a ser vista por alguns, como sendo apenas um pré-requisito para o acesso a uma Residência em outra especialidade.

A maioria dos Serviços de Cirurgia Geral credenciados pela Comissão Nacional de Residência Médica (CNRM) dispõe apenas de dois anos para treinar um cirurgião geral, sendo o primeiro ano quase que totalmente ocupado com rodízios inoperantes em outras especialidades.

Alguns serviços têm direito a mais um ano para participação em videocirurgia e trauma, áreas consideradas como de atuação. É muito pouco para formar um cirurgião geral.

Somam-se a estas dificuldades a necessidade do residente procurar complementar o seu aprendizado com alternativas paralelas de prática cirúrgica que, na maioria das vezes, são insuficientes e inapropriadas devido à precariedade de orientação.

A previsão quanto a uma remuneração futura pouco expressiva é também um fator a ser considerado e que, sem dúvida, influi na procura por uma especialidade com perspectivas de retomo econômico maior e mais rápido.
O Colégio Brasileiro de Cirurgiões, apreensivo em relação a esta realidade e preocupado com a formação do cirurgião geral, criou em 1992 e em 2011 duas novas categorias de membros: os Aspirantes e os Acadêmicos.

Dentre várias justificativas usadas para inserir estas duas novas categorias, uma foi a de criar uma forma capaz de mostrar aos futuros e aos novos médicos (residentes e acadêmicos de medicina) as diversas ações do Colégio na valorização da Cirurgia Geral como especialidade.

A procura por estas novas categorias tem correspondido às nossas expectativas, o que é muito salutar para o CBC, que renova o seu quadro de membros e cria um incentivo a mais pela procura da especialidade.

Além dos mecanismos existentes de aprendizado e de complemento à formação médica obtida na graduação, o Colégio também dá a estes novos membros a oportunidade de obterem o Título de Especialista em Cirurgia Geral. O Colégio é uma instituição autorizada pela Associação Médica Brasileira para a aplicação do concurso específico.

O CBC, no momento, consegue ter uma participação bastante expressiva junto à Residência Médica em Cirurgia Geral. O fato de poder influir na criação de novas alternativas capazes de conduzir a uma orientação mais objetiva e consistente na formação do cirurgião geral sempre foi um dos objetivos da instituição.

A geração de meios capazes de proporcionarem conhecimentos necessários ao seu associado para que possa exercer a especialidade com segurança sempre foi e continuará a ser uma prioridade de suas metas de ação. Para isto dispõe de várias Comissões capazes de apoiar na implantação e no continuísmo de diversas ações definidas pelo Diretório Nacional.

Uma delas, a Comissão de Residência Médica, composta por pessoas interessadas e atuantes na área, conseguiu com que obtivéssemos dois importantes avanços na relação entre o CBC e a CNRM. Um ao ter vários de seus membros envolvidos com a avaliação e controle nacional dos Serviços com Residência Médica em Cirurgia Geral e o outro em participar da elaboração das novas matrizes didáticas para atualização dos programas vigentes.

A participação do Colégio nesses projetos deverá trazer perspectivas de melhores momentos para a Residência em Cirurgia Geral no Brasil e, consequentemente, para os futuros cirurgiões gerais.

Para que isto aconteça e possamos ter uma participação mais ativa e determinada para podermos colocar 
os nossos sonhos em prol de uma Residência em Cirurgia Geral mais consistente é necessária e imprescindível a participação proativa do maior número possível de membros do CBC.

O fato de pertencermos a uma instituição impar no cumprimento de normas estatutárias e regimentais nos permite ter mecanismos de orientação de conduta uniformes, que são capazes de legitimar as nossas propostas de forma inigualável, o que facilita influenciar em mudanças e benefícios para a Cirurgia Geral no nosso país.
Esperamos poder exercer com o máximo de agilidade, presteza e firmeza todas as formas capazes de melhorar as condições do cirurgião brasileiro tanto na orientação da sua formação como na sua qualificação, mas para que isto aconteça, é necessário que mantenhamos o nosso foco de ação sempre voltado para o coletivo, priorizando ações que façam reacender o interesse pela Cirurgia Geral, fator imprescindível para a prestação de um atendimento adequado à população de um país como o nosso. 